\title{
Performance Analysis of the Natural Draft Cooling Tower in Different Seasons
}

\author{
T.Jagadeesh, Dr.K.Subba Reddy. \\ 1 ( Mechanical Engineerig, G.Pulla Reddy Engineerig College (Autonomous) /J NTU Anantapur , India) \\ 2 (Mechanical Engineerig, G.Pulla Reddy Engineerig College (Autonomous) /J NTU Anantapur, India)
}

\begin{abstract}
Cooling towers are the biggest heat and mass transfer devices that are in widespread use. In this paper we use a natural draft counter flow cooling tower in investigating the performance of cooling tower in different seasons. The humidity is defined as water particles present in air. The humidity is the major factor in the atmosphere, it depends upon ambient temperature. Humidity is high in winter season and low in summer season.

The performance of the natural draft cooling tower is dominated by wind speed, ambient air temperatures and humidity in the atmospheric conditions. When the humidity is high in atmosphere, large quantity of water is required for cooling condensate. When humidity is low in atmosphere, small quantity of water is required for cooling condensate. The value of relative humidity in the atmosphere varies from place to place and season. The different losses in the cooling tower such as drift losses, evaporation losses and blow down losses can be calculated. The maintenance of cooling tower in the form of removal of scale or corrosion plays important role in the performance of the tower. The performance of the natural draft cooling tower of 500 $M W$ is evaluated.
\end{abstract}

Keywords: Cooling tower, cycle of concentration, DBT, HVAC, losses, Relative humidity, WBT

\section{Introduction}

A cooling tower is a semi closed device for evaporative cooling of water by contact with air. The main function of cooling tower is to remove waste heat into the atmosphere from condenser. Cooling towers are an integral part of much industrial processes such as oil refineries, thermal power plants, petrochemical and chemical plants and HVAC system for cooling buildings. The cool water absorbs heat from the condenser becomes warmer. The warm water then returns to the cooling tower. In cooling tower the warm water sprayed downward, and air is blown upward. As the warm water droplets contact the air, some of the water droplets evaporate, and the air absorbs the heat released to the atmosphere, thereby lowering the temperature of the remaining water. In dry cooling tower the air is passed through the finned tubes forming a heat exchanger so only sensible heat is transferred to the air. In wet cooling towers the water is sprayed directly into the air. When evaporation occurs, both latent heat and sensible heat is exchanged.

In cooling tower the ambient air is used to cool warm water coming from the condenser. They are many cooling tower designs or configurations. In natural draft towers are used very large thermal power plant and chemical plants. Due to large size of towers, they are generally used for water flow rates above $45000 \mathrm{~m}^{3 /}$ hr. Mechanical draft cooling towers utilize large fan to force or suck air through circulated water. Mechanical draft towers, tend to be relatively small structures where the air flow is driven by fan. The density difference between the warm air inside the tower and the cool dense ambient air outside the tower. A further classification is between counter flow and cross flow cooling towers. In cross flow cooling tower, the air flows at some angle to water flow direction and counter flow cooling tower, the air flows in the opposite direction to water flow direction.

\section{Natural Draft Counter Flow Cooling Tower}

This study is concerned with natural draft counter flow cooling tower. This type of towers is found in large power plants. There are three zones: 1 . Spray zone 2 . Fill zone 3 . Rain zone 


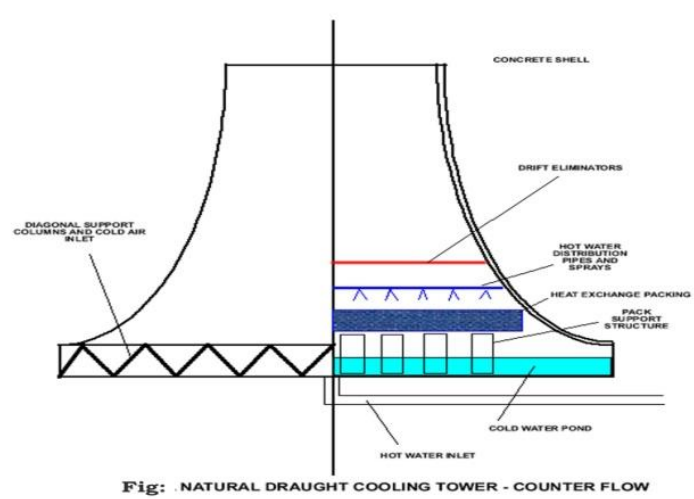

The hot water is introduced into the tower through spray nozzles approximately $10 \mathrm{~m}$ above the basin. The main function of the spray zone is to simply distribute the water evenly across the tower. The water passes through a small spray zone as the fast moving droplets before entering the fill. There are a range of fill types. Generally they tend to be either a splash fill or film fill type. The splash fill type acts to break up water flow into smaller droplets with splash bars. A film fill is a more modern design which forces the water to flow in film over closely packed parallel plates. This significantly increases the surface area for heat and mass transfer.

\subsection{Dry Bulb Temperature And Wet Bulb Temperature}

\section{Factors Affecting Cooling Tower Performance}

The dry bulb temperature (DBT) is the temperature of air measured by a thermometer freely exposed to the air but shielded from radiation and moisture. The wet bulb is a measure of the quantity of moisture a particular sample of air can hold at that particular moment. Wet bulb temperature is an important factor in performance of evaporative water cooling equipment.

\subsection{Humidity Of The Ambient Air}

Humidity is defined as water particles presented in the air. The humidity is high in coastal areas and low in non coastal areas. Humidity is high in atmosphere, high quantity of water is required for cooling condensate.

\subsection{RANGE}

\section{Assesment Of Cooling Tower}

Range is the difference between the cooling tower water inlet and outlet temperature. A high cooling tower range means that the tower has been able to reduce the water temperature effectively, and thus performance is well.

\subsection{APPROACH}

Approach is the temperature difference between the cooling tower outlet temperature and ambient wet bulb temperature.

\subsection{EFFECTIVENESS}


It is the ratio between the range and the ideal range, i.e. difference between cooling water inlet temperature and ambient wet bulb temperature, or in other words it is =Range / (Range + Approach).

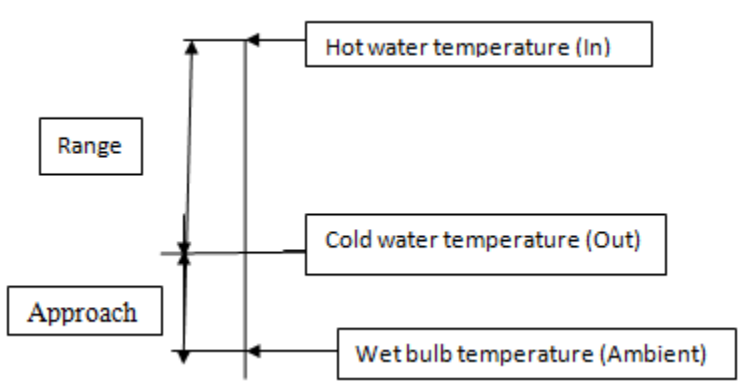

Fig 2: Range and of Approach of cooling tower

\section{Specifications Of Natural Draft Counter Flow Cooling Tower}

\begin{tabular}{|l|l|}
\hline Tower height & $151 \mathrm{~m}$ \\
\hline Air inlet height & $8.6 \mathrm{~m}$ \\
\hline Fill depth & $1.8 \mathrm{~m}$ \\
\hline Tower basin diameter & $110.2 \mathrm{~m}$ \\
\hline Fill base diameter & $101 \mathrm{~m}$ \\
\hline Tower top diameter & $66 \mathrm{~m}$ \\
\hline Spray zone height & $0.8 \mathrm{~m}$ \\
\hline
\end{tabular}

\begin{tabular}{|l|l|l|}
\hline Parameters & Winter & Summer \\
\hline Dry bulb temperature & $33^{\circ} \mathrm{C}$ & $36.05^{\circ} \mathrm{C}$ \\
\hline Wet bulb temperature & $27^{\circ} \mathrm{C}$ & $28.06^{\circ} \mathrm{C}$ \\
\hline Hot water temperature $\left(\mathbf{T}_{\mathbf{1}}\right)$ & $40.05^{\circ} \mathrm{C}$ & $42.82^{\circ} \mathrm{C}$ \\
\hline Cold water temperature $\left(\mathbf{T}_{\mathbf{2}}\right)$ & $29.75^{\circ} \mathrm{C}$ & $33.4^{\circ} \mathrm{C}$ \\
\hline Relative humidity & $63 \%$ & $55 \%$ \\
\hline Mass flow rate of water in cooling tower & $64146.83 \times 1000 \mathrm{Kg} / \mathrm{hr}$ & $63196.74 \times 1000 \mathrm{Kg} / \mathrm{hr}$ \\
\hline
\end{tabular}

\section{DATA FROM PSYCHROMETRIC CHART AND STEAM TABLE}

\begin{tabular}{|c|c|c|}
\hline & Winter season & Summer season \\
\hline Enthalpy of air at in let temperature $\left(\mathrm{H}_{\mathrm{a} 1}\right)$ & $77 \mathrm{~kJ} / \mathrm{kg}$ & $78.5 \mathrm{~kJ} / \mathrm{kg}$ \\
\hline Enthalpy of air at in let temperature $\left(\mathrm{H}_{\mathrm{a} 2}\right)$ & $117 \mathrm{~kJ} / \mathrm{kg}$ & $125 \mathrm{~kJ} / \mathrm{kg}$ \\
\hline $\begin{array}{l}\text { Specific humidity of air at inlet } \\
\text { temperature }\left(W_{1}\right)\end{array}$ & $0.0203 \mathrm{~kg} / \mathrm{kg}$ of air & $0.0208 \mathrm{~kg} / \mathrm{kg}$ of air \\
\hline $\begin{array}{l}\text { Specific humidity of air at outlet } \\
\text { temperature }\left(W_{2}\right)\end{array}$ & $0.0365 \mathrm{~kg} / \mathrm{kg}$ of air & $0.039 \mathrm{~kg} / \mathrm{kg}$ of air \\
\hline $\begin{array}{l}\text { Specific volume of air at inlet } \\
\text { temperature }\left(V_{S 1}\right)\end{array}$ & $0.895 \mathrm{~m}^{3} / \mathrm{hr}$ & $0.908 \mathrm{~m}^{3} / \mathrm{hr}$ \\
\hline $\begin{array}{l}\text { Specific volume of air at outlet } \\
\text { temperature }\left(V_{S 2}\right)\end{array}$ & $0.927 \mathrm{~m}^{3} / \mathrm{hr}$ & $0.930 \mathrm{~m}^{3} / \mathrm{hr}$ \\
\hline $\begin{array}{l}\text { Enthalpy of water at inlet } \\
\text { temperature }\left(\mathbf{H}_{\mathrm{w} 1}\right)\end{array}$ & $167.57 \mathrm{~kJ} / \mathrm{kg}$ & $179.26 \mathrm{~kJ} / \mathrm{kg}$ \\
\hline $\begin{array}{l}\text { Enthalpy of water at inlet } \\
\text { temperature }\left(\mathrm{H}_{\mathrm{w} 1}\right)\end{array}$ & $124.74 \mathrm{~kJ} / \mathrm{kg}$ & $139.99 \mathrm{~kJ} / \mathrm{kg}$ \\
\hline
\end{tabular}

\subsection{WINTER SEASON}

\section{Calculation}

Cooling tower range $=$ hot water temperature - cold water temperature

$$
\begin{aligned}
& =40.05^{\circ} \mathrm{C}-29.75^{\circ} \mathrm{C} \\
& =10.3^{\circ} \mathrm{C}
\end{aligned}
$$

Cooling tower approach $=$ cold water temperature - wet bulb temperature

$$
\begin{aligned}
& =29.75^{\circ} \mathrm{C}-27^{\circ} \mathrm{C} \\
& =2.75^{\circ} \mathrm{C}
\end{aligned}
$$

Efficiency of cooling tower $=$ range $/($ range + approach $)$

HEAT LOSS BY WATER (HL)

$\mathrm{HL}=\mathrm{M}_{\mathrm{w} 1} \times \mathrm{C}_{\mathrm{pw}} \times\left(\mathrm{T}_{1}-\mathrm{T}_{2}\right)$ 
$\mathrm{HL}=64146.83 \times 10^{3} \times 4.186 \times(40.05-29.75)$

$\mathrm{HL}=2765741.893 \mathrm{MJ} / \mathrm{hr}$

VOLUME OF AIR REQUIRED (V)

$\mathrm{V}=\left(\mathrm{HL} \times \mathrm{V}_{\mathrm{s} 1}\right) /\left(\left(\mathrm{H}_{\mathrm{a} 2}-\mathrm{H}_{\mathrm{a} 1}\right)-\left(\mathrm{W}_{2}-\mathrm{W}_{1}\right) \times \mathrm{C}_{\mathrm{pw}} \times \mathrm{T}_{2}\right)$

$\mathrm{V}=(2765741893 \times 0.895) /((117-77)-(0.0365-0.0203) \times 4.186 \times 29.75)$

$\mathrm{V}=65170512.58 \mathrm{~m}^{3} / \mathrm{hr}$

\section{HEAT GAIN BY AIR (HG)}

$\mathrm{HG}=\mathrm{V} \times\left(\left(\mathrm{H}_{\mathrm{a} 2}-\mathrm{H}_{\mathrm{a} 1}\right)-\left(\mathrm{W}_{2}-\mathrm{W}_{1}\right) \times \mathrm{C}_{\mathrm{pw}} \times \mathrm{T}_{2}\right) / \mathrm{V}_{\mathrm{s} 1}$

$\mathrm{HG}=65170512.58 \times((117-77)-(0.0365-0.0203) \times 4.186 \times 29.75)$

$\mathrm{HG}=2765741893 \mathrm{KJ} / \mathrm{hr}$

MASS OF AIR REQUIRED $\left(M_{\text {air }}\right)$

$\mathrm{M}_{\mathrm{air}}=$ volume of air required/specific volume of air at inlet temperature

$\mathrm{M}_{\mathrm{air}}=\mathrm{V} / \mathrm{V}_{\mathrm{s} 1}$

$\mathrm{M}_{\text {air }}=65170512.18 / 0.895$

$\mathrm{M}_{\mathrm{air}}=72816214.73 \mathrm{Kg} / \mathrm{hr}$

DIFFERENT TYPES LOSSES

Drift losses:

Drift losses are generally taken as $0.002 \%$ to $0.005 \%$.

Drift losses $=0.002 \% \times$ mass flow rate of water

$$
\begin{aligned}
& =(0.002 / 100) \times 64146 \times 10^{3} \\
& =1282.9 \mathrm{Kg} / \mathrm{hr}
\end{aligned}
$$

Evaporation losses:

Evaporation losses are generally taken as 0.00085 of circulating water

$=0.00085 \times 1.8 \times 64146.83 \times 10^{3} \times\left(\mathrm{T}_{1}-\mathrm{T}_{2}\right)$

$=1010889 \mathrm{~kg} / \mathrm{hr}$

Blow down losses:

Blow down losses= evaporation losses / coc-1

\subsection{SUMMER SEASON}

$$
\begin{aligned}
& =1010889 / 4-1 \\
& =336963 \mathrm{Kg} / \mathrm{hr}
\end{aligned}
$$

Cooling tower range $=$ hot water temperature - cold water temperature

$$
\begin{aligned}
& =42.82^{\circ} \mathrm{C}-29.75^{\circ} \mathrm{C} \\
& =9.42^{\circ} \mathrm{C}
\end{aligned}
$$

Cooling tower approach $=$ cold water temperature - wet bulb temperature

$$
\begin{aligned}
& =33.4^{\circ} \mathrm{C}-28.06{ }^{\circ} \mathrm{C} \\
& =5.34^{\circ} \mathrm{C}
\end{aligned}
$$

Efficiency of cooling tower $=$ range $/($ range + approach $)$

$$
\begin{aligned}
& =9.42 /(9.42+5.34) \\
& =63.82 \%
\end{aligned}
$$

HEAT LOSS BY WATER (HL)

$\mathrm{HL}=\mathrm{M}_{\mathrm{w} 1} \times \mathrm{C}_{\mathrm{pw}} \times\left(\mathrm{T}_{1}-\mathrm{T}_{2}\right)$

$\mathrm{HL}=63196.74 \times 10^{3} \times 4.186 \times(42.82-33.4)$

$\mathrm{HL}=2491981.485 \mathrm{MJ} / \mathrm{hr}$

VOLUME OF AIR REQUIRED (V)

$\mathrm{V}=\left(\mathrm{HL} \times \mathrm{V}_{\mathrm{s} 1}\right) /\left(\left(\mathrm{H}_{\mathrm{a} 2}-\mathrm{H}_{\mathrm{a} 1}\right)-\left(\mathrm{W}_{2}-\mathrm{W}_{1}\right) \times \mathrm{C}_{\mathrm{pw}} \times \mathrm{T}_{2}\right)$

$\mathrm{V}=(2491981485 \times 0.895) /((125-78.5)-(0.039-0.0208) \times 4.186 \times 33.4)$

$\mathrm{V}=51477615.68 \mathrm{~m}^{3} / \mathrm{hr}$

\section{HEAT GAIN BY AIR (HG)}

$\mathrm{HG}=\mathrm{V} \times\left(\left(\mathrm{H}_{\mathrm{a} 2}-\mathrm{H}_{\mathrm{a} 1}\right)-\left(\mathrm{W}_{2}-\mathrm{W}_{1}\right) \times \mathrm{C}_{\mathrm{pw}} \times \mathrm{T}_{2}\right) / \mathrm{V}_{\mathrm{s} 1}$ $\mathrm{HG}=51477615.68 \times((125-78.5)-(0.039-0.0208) \times 4.186 \times 33.4) / 0.908$

$\mathrm{HG}=2491981485 \mathrm{~kJ} / \mathrm{hr}$

\section{MASS OF AIR REQUIRED $\left(M_{\text {air }}\right)$}

$\mathrm{M}_{\mathrm{air}}=$ volume of air required/specific volume of air at inlet temperature

$\mathrm{M}_{\mathrm{air}}=\mathrm{V} / \mathrm{V}_{\mathrm{s} 1}$

$\mathrm{M}_{\text {air }}=51477615.68 / 0.908$

$\mathrm{M}_{\mathrm{air}}=56693409 \mathrm{~kg} / \mathrm{hr}$ 


\section{DIFFERENT TYPES OF LOSSES}

Drift losses:

Drift losses are generally taken as $0.002 \%$ to $0.005 \%$.

Drift losses $=0.002 \% *$ mass flow rate of water

Evaporation losses:

$$
\begin{aligned}
& =(0.002 / 100) \times 63196.74 \times 10^{3} \\
& =1282.9 \mathrm{~kg} / \mathrm{hr}
\end{aligned}
$$

Evaporation losses are generally taken as 0.00085 of circulating water

$=0.00085 \times 1.8 \times 63196.74 \times 10^{3} \times\left(\mathrm{T}_{1}-\mathrm{T}_{2}\right)$

$=0.00085 \times 1.8 \times 63196.74 \times 10^{3} \times(42.82-33.4)$

$=910829.33 \mathrm{~kg} / \mathrm{hr}$

Blow down losses:

Blow down losses= evaporation losses /coc-1

$$
\begin{gathered}
=910829.33 / 4-1 \\
=303609 \mathrm{Kg} / \mathrm{hr}
\end{gathered}
$$

\section{Results And Conclusions}

Two observations are as shown below,

\begin{tabular}{|l|l|l|}
\hline Parameter & Winter season & Summer season \\
\hline Range & $10.3^{\circ} \mathrm{C}$ & $9.42^{\circ} \mathrm{C}$ \\
\hline Approach & $2.75^{\circ} \mathrm{C}$ & $5.34^{\circ} \mathrm{C}$ \\
\hline Efficiency of cooling tower & $78.92 \%$ & $63.82 \%$ \\
\hline Heat loss by water & $2765741 \mathrm{MJ} / \mathrm{kg}$ & $2491981 \mathrm{MJ} / \mathrm{kg}$ \\
\hline Mass of air & $72816214.73 \mathrm{~kg} / \mathrm{hr}$ & $56693409.3473 \mathrm{~kg} / \mathrm{hr}$ \\
\hline Drift losses & $1282.9 \mathrm{~kg} / \mathrm{hr}$ & $1263.93 \mathrm{~kg} / \mathrm{hr}$ \\
\hline Evaporation losses & $1010899 \mathrm{~kg} / \mathrm{hr}$ & $910829.33 \mathrm{~kg} / \mathrm{hr}$ \\
\hline Blow down losses & $336963 \mathrm{~kg} / \mathrm{hr}$ & $303609.77 \mathrm{~kg} / \mathrm{hr}$ \\
\hline
\end{tabular}

The efficiency of the cooling tower is high in winter season as comparison to summer season. The efficiency of cooling tower in winter season $78.92 \%$. Efficiency of cooling tower in summer season $=63.82 \%$ the cooling tower efficiency difference between summer season and winter season is $=15.10 \%$

The cooling tower is closely related to different types of losses generated in cooling tower. The losses of the cooling tower are high in winter season as compare to summer season. We can conclude that by increasing the efficiency of cooling tower is built in non coastal areas (Humidity is low) we can increase the cooling tower efficiency.

\section{References}

[1]. P.K. Nag Engineering Thermodynamics; Tata McGraw Hill publications

[2]. Arora and Domakundwar, power plant engineering, dhanpat rai \& co.,

[3]. Z. Zhai, S. FU, Improving cooling efficiency of dry cooling towers under cross wind conditions by using wind break methods, Applied Thermal Engineering 26(2004) 914-923

[4]. A.K.M. Mohiuddin, K. Kant, knowledge base for the systematic design of wet cooling tower.

[5]. J. Smrekar, I .Kustrin, J. Oman, methodology for evaluation of cooling tower performance -part 1:description of the methodology, Energy Conversion and management 52 (2011) 3257-3264

[6]. B.T. Nijaguna, Thermal Science data book.

[7]. Fisenko, S.P.,Petruchik, A.I. and Solodukhin, A.D .Evaporative cooling of water in a natural draft cooling tower. International Journal of Heat and Mass Transfer, 45:4683-4683-4694, 2002

[8]. Mohiuddin AKM, Kant K. Knowledge base for the base for the systematic design of wet cooling towers. Part II: fill and other design parameters. Int J Refrig 1996;19(1):52-60. 